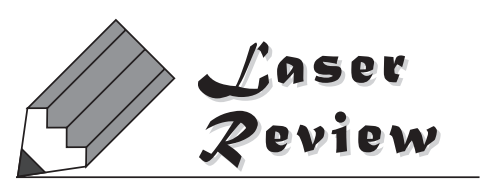

\title{
フェムト秒レーザーによる金属ナノ周期構造の形成と摩擦低減加工機への応用
}

\author{
加藤 貴行 $^{1}, \quad$ 阿部 信行 $^{2}$ \\ ${ }^{1}$ エンシュウ(株)（†432-8522 静岡県浜松市南区高塚町4888） \\ ${ }^{2}$ 大阪大学 接合科学研究所 ( T 567-0047 大阪府茨木市美穂ヶ 丘11-1)
}

\section{Formation of Metallic Nano Periodic Structures by Femto-Second Laser and Its Application to Low Friction Parts Machining System}

\author{
Takayuki KATOU ${ }^{1}$ and Nobuyuki $\mathrm{ABE}^{2}$ \\ ${ }^{1}$ ENSHU Limited, 4888 Takatsuka-Cho, Minami-Ku, Hamamatsu, Shizuoka 432-8522 \\ ${ }^{2}$ Joining and Welding Research Institute, Osaka University, 11-1 Mihogaoka, Ibaraki, Osaka 567-0047
}

(Received January 29, 2009)

\begin{abstract}
Femto-second laser can form metallic nano periodic structures on metal parts near there ablation threshold flunce. These nano periodic structures are thought to be one of the method to decrease the friction coefficient of metallic surface. We have developed a femto-second laser machining system for lowering friction on mechanical parts. This system consists of a femto-second laser, an optical beam shaper, and a five axes mechanical stage. The optical beam shaper can change a profile to be effective for the periodic structure formation using a phase plate. With this system, various pattern of periodic structure was formed even on curved surfaces of parts such as ball bearings and inner surfaces of engine cylinder. We investigated the effect of friction reduction by the nano periodic structures.
\end{abstract}

Key Words: Femto-second laser, Nano periodic structures, Low friction mechanical parts

1. はじめに

フェムト秒レーザー装置の技術開発は年々進み，それ に伴いフェムト秒レーザーの特徴を生かした加工技術も 発展してきた。フェムト秒レーザーによる加工は，熱拡 散による素材への影響が少ないことから, 精密な微細加 工や, 非線形効果による局所的な加工や改質を, 3次元 加工で行うなど様々な特徵的な加工を行う事ができ注目 されている。特に, 微細加工の分野では金属, 非金属, 又は生体関連材料など, 様々な分野での発展が目覚まし く, 周期的なナノメートルオーダーの溝加工が簡易に加 工できるのが特徴である ${ }^{1-3)}$.

筆者らはこのフェムト秒レーザーを使った加工が, 自 動車エンジン等の摺動部品を持つ駆動系の省エネルギー 化に活用できるのではないかと考え, 産業応用として取 り組み, 『平成 $17 \cdot 18$ 年度地域新生コンソーシアム研究 開発事業』にて, 『フェムト秒レーザーを使った省エネル ギー・長寿命部品加工機の開発』を行い, 形成される構 造が摺動部の摩擦低減に効果があることについて実証し た。本稿ではその内容とこれからの展望について紹介す る.
2. ナノ周期構造の形成と応用について

フェムト秒レーザーによる特徵的な加工のひとつに, ナノ周期構造を形成する方法が報告されている年3 . 直 線偏光のフェムト秒レーザーを, 加工対象となる物質の アブレーションしきい值近傍のフルーエンスで照射する と, 物質表面に周期的な溝形状 (以下, ナノ周期構造) を 形成する事が出来る。このナノ周期構造は照射したレー ザースポット内に自己組織的に形成されるものであり， この時, ナノ周期構造は照射したレーザーの偏光方向に 直交した方向に形成される。ナノ周期構造の大きさは溝 幅(ピッチ), 溝深さが数百 $\mathrm{nm}$ 程度であり，照射した レーザーの波長サイズの周期的な溝形状が形成される. このナノ周期構造の形状は，レーザーの照射条件により 変化させる事が可能である，例えば，照射角度を変更する 事でナノ周期構造のピッチを変化させる事が出来る ${ }^{4-6)}$. ナノ周期構造の加工は, 金属や半導体などの非鉄金属な ど, 様々な対象物へ加工する事が出来る。十ノ周期構造 加工の研究は数多く行われ, 加工原理, 条件などについ て研究が進んでいる。最近ではナノ周期構造を実用展開 する為のアプリケーションの開発について取り組まれは じめた。例えば金属表面に機能性セラミックスやDLC等 をコーティングする際, 密着性を向上させるために, 微 
細構造を形成させると有効である事や》，ナノレベルの 凹凸形状が細胞感受性に影響を与える事が出来るため, 人工関節などに使用されるチタンを加工する事で人体親 和性の低下を抑制する効果など8 , ナノ周期構造の機能 性について研究報告がされ始めている。筆者らはナノ周 期構造が作る微細な凹部が, 摺動面に使用される潤滑油 の保持能力を向上させることにより, 摩擦倸数の低隇効 果から省エネルギー化を図れることを期待して研究を進 めた。

\section{3. ナノ周期構造の金属摺動部品への応用}

地球を取り巻く環境は年々悪化して抢り, フロン等に よるオゾン層破壊，大気中の温室効果ガスの増加による 地球温暖化や，それに伴うモントリオール議定書，京都 議定書など環境改善の取り組みは世界規模で行われてき た。国内でも経済産業省等により，エネルギー・環境技 術分野の技術開発が国の支援により積極的に行われてき た。そして近年ではその取り組み意識, 活動は国から企 業へと移り, 地球環境問題は企業の責任であると同時 に，非常に大きな市場規模を持つビジネスのひとつに なっている, 環境問題の改善方法のひとつに省エネル ギー化の取り組みがあり，そのうちのひとつに摺動部品 の摩擦抵抗を減らす為に, トライボロジーの研究が取り 組まれ, 実用部品への展開が進められている。例えば レーザーでエンジンシリンダを加工し，省エネルギー化 に取り組んだ研究が行われた。シリンダブロックの摺動 部分に数 $\mu \mathrm{m}$ の深さの溝を，数百 $\mu \mathrm{m} の$ 間隔で加工するこ とで, 長期間の摺動実験に打いて, 従来に比べて潤滑油 の使用量が $15 \sim 30 \%$ 減り，粉塵量も 40〜60\%削減する ことが報告された，この溝の加工は，1本毎にレーザー を収束し加工する方法で製作されており，フェムト秒 レーザーはナノ秒レーザーより溝の形状が精密に加工で きる事から, レーザー加工後の処理が不要になり, 効果 的であるが，フェムト秒レーザーでの加工時間は非常に 長く, フルーエンス $5 \mathrm{~J} / \mathrm{cm}^{2}$, パルス幅120 fsに扔いて, 加工速度が $0.6 \mathrm{~mm} / \mathrm{min}$ 程度であった。 その為，一般的な 産業用に使用されるにはコス卜，生産能力の面に扔いて 課題が改善できず，実用的では無いと報告されている9

しかし，先に述べたフェムト秒レーザーを使用したナ ノ周期構造の形成による溝加工ならば，照射スポット内 に溝形状が同時に複数加工できるため, 加工時間は従来 の方法に比べて非常に短く, 生産能力の面で大きく改善 され, 産業用としての摩擦の低減効果に活用できると考 えられる。この微細なナノメートルオーダーの溝構造が 摩擦低減の効果があるかを検証し，最終的な目標として 実用部品への加工, エンジンシリンンダ内面へ加工が行 えるシステム開発の研究を行った。

\section{4. ナノ周期構造の摩擦係数低減効果}

フェムト秒レーザーによる金属表面へのナノ周期構造 形成や，加工したナノ周期構造の摩擦係数への影響につ
いて研究を行った ${ }^{10)}$. ピンオンデイスク摩擦試験で摩擦 係数の測定を行った。用いた摩擦試験機 (CSM 社製 TRIBOMETER)に扔いて，試料としてSCM415(合金鋼） を使用し， S45C(鋼材) との間の摩擦係数を測定した. 試料の表面に周期構造を加工した場合と未処理の場合と の比較計測を行った.SCM415の試料に加工速度 $5 \mathrm{~mm} /$ $\mathrm{sec}$ ，フルーエンス $0.5 \mathrm{~J} / \mathrm{cm}^{2}$ で周期構造を加工した。試料 上での溝の加工状態と拡大写真をFig. 1に示す。溝の方 向は図中の点線に沿うょうに中心から弧を描いて外側に 向かう形状をしている.

摺動試験条件は負荷加重 $1.27 \mathrm{~N} / \mathrm{cm}^{2}$, 摺動速度 $0.5 \mathrm{~cm} /$ $\mathrm{sec}$ ，金属間には潤滑油(タービン専用オイル：大澤ワッ クス(株)製，TA-1K）を浸した．Fig. 2に摩擦係数測定結 果を示す, 周期構造なしの摩擦係数は 0.08 , 標準偏差は 0.020 に対して, 周期構造を加工した金属間の摩擦倸数 は 0.06 未満, 標準偏差は 0.006 となった。二つの摩擦係数 を比較すると，十ノ周期構造を付加する事で摩擦係数が 約 $25 \%$ 程度低減している事が分かる. $25 \%$ の摩擦係数 の軽減は, 例えば自動車のエンジンシリンダについて考 えてみると，エンジン内のエネルギー配分は，エンジン

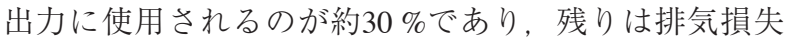
が約 $30 \%$ ，冷却損失が約 $30 \%$ ，摩擦損失が約 $10 \%$ とな ると言われている ${ }^{11}$ 。この摩擦損失の部分が軽減される 事で，全体として2〜3\%程度の省エネルギー化になる と考えられる。

また周期構造を付加しない試料は, 摩擦係数が変動す る幅が広い事が分かる。これはスティックスリップ現象 と言われるもので, 静摩擦係数と動摩擦係数が原因で, 引っ掛かりと急激な滑りの減少が交互に起きる事で発生 するとされている ${ }^{12}$. スティックスリップ現象は製品の 寿命劣化などに影響するため, この減少を抑えることも
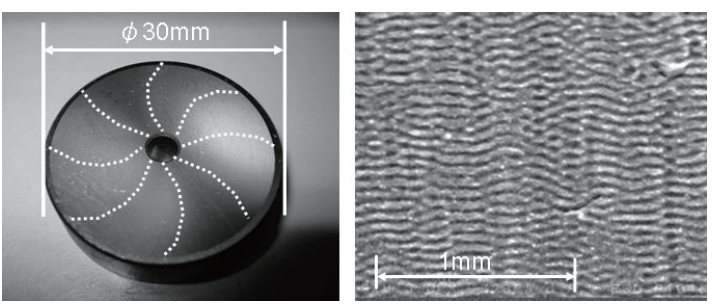

Fig. 1 A typical sample with nano periodic structures for friction test. Nano periodic structures were formed in a radial pattern as shown by dotted lines.

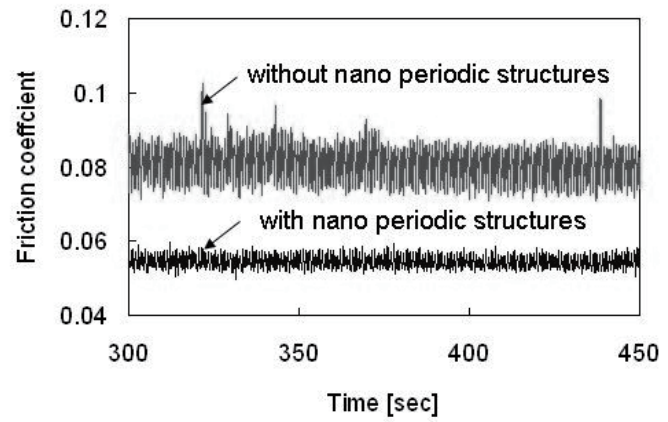

Fig. 2 The comparison of the friction coefficient on the samples between with and without nano periodic structures. 
摺動部品には非常に重要であり,この面においてもナノ 周期構造は効果的であると考えられる.

実用化を考慮した場合，このナノ周期構造の耐久性が 問題となる。ナノ周期構造の大きさは溝幅 $500 \mathrm{~nm}$ $600 \mathrm{~nm}$, 溝深さ200 nm〜400 nmと非常に小さな構造で ある。この周期構造が摩擦により摩耗を抑える事が重要 になる。ボールオンオンディスクによる摺動試験におい て寿命の検証を行った。前試験と同じSCM415材料の表 面に周期構造を加工した物と，表面研磨だけの物を比較 した。摺動させる相手材料はSUJ2 (軸受鋼), $\phi 3.2 \mathrm{~mm}$ の ボールを使用した。負荷加重 $1.27 \mathrm{~N} / \mathrm{cm}^{2}$, 摺動速度は $3 \mathrm{~m} / \mathrm{min}$, 接触面には前試験と同様に潤滑油を浸して 行った。 円形試料の半径 $4.53 \mathrm{~mm}$ の位置で接触させてい る為, 試験時間の 20 時間の間に約 12.7 万回同一箇所で接 触している事になる。試料の表面SEM像をFig. 3に，摩 擦係数の測定結果をFig. 4に示す. 表面研磨のみの試料 は, 初期に少し摩擦係数が変動しているものの, 後半に は初期值とほぼ同じ高い摩擦係数を示していた。 それに 対し, 周期構造を付加した試料は, 時間の経過と共に摺 動表面のナノ周期構造が徐々に無くなっていく事が分か る. Fig. $3(\mathrm{a}) \sim(\mathrm{d})$ より判断すると摩擦抵抗は元の未処 理の状態に近づくように思われるが, 摩擦係数の測定結 果をみると周期構造が減少するのに反して, 摩擦係数は 減少し安定していくことが分かる，表面粗さの突起が大 きい部分は接触圧が大きい為, 摩耗が促進され, 初めの 早い段階において初期摩耗として周期構造がなくなると

(I) With nano periodic structures.

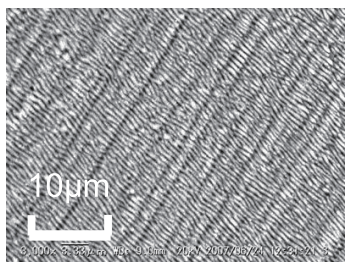

(a) $0 \mathrm{~min}$

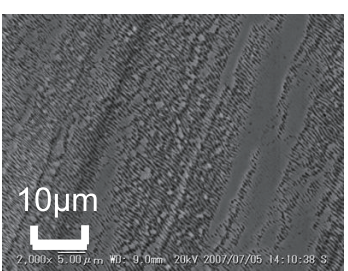

(c) $2 \mathrm{~h}$

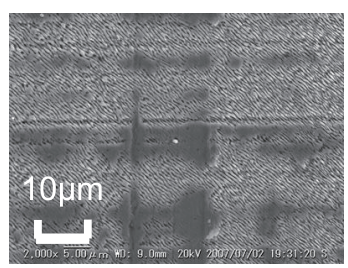

(b) $2 \mathrm{~min}$

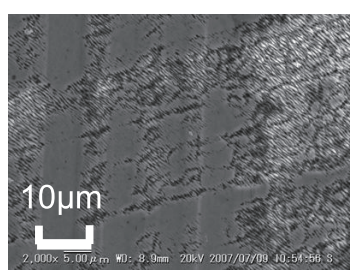

(d) $20 \mathrm{~h}$
(II) Without nano periodic structures.

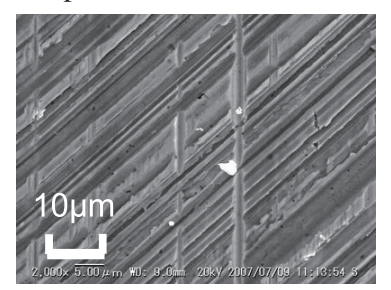

(e) $20 \mathrm{~h}$

Fig. 3 SEM pictures of sample surface before (a) and after (b)-(e) the friction test. (I) with nano periodic structures, and (II) without nano periodic structures.

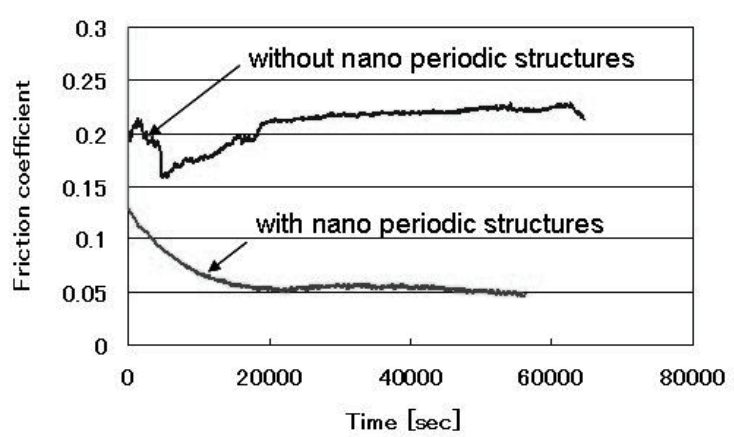

Fig. 4 Dependence of friction coefficient on testing time.

考えられる。しかし，突出した突起部分が無くなり，定 常摩耗状態に近づくにつれ，潤滑効果が現れ，摩耗の促 進を抑えているものと筆者らは推察している。

\section{5. 省エネルギー・長寿命部品加工機の開発}

開発機のシステムは大きく分けて3つの構成 (レーザー 発振部, レーザー整形部, ステージ部)にて成り立って いる. 概観，構成図をFig. 5に，レーザーと加工機の仕 様をTable 1 に示す．動作軸はワーク等を保持するステー ジ部の直線3軸 $(\mathrm{X}, \mathrm{Y}, \mathrm{Z})$, 回転1軸 $(\mathrm{C})$ と, レーザー光 を360度回転させる回転1軸 $(\mathrm{L})$ の構成になっている.

まず産業用装置として様々なワークに加工できるよう な自由度がある事を前提とした。特に今回の装置ではエ ンジンシリンダを想定し，円筒内面加工において自由度 をもたせた。 円筒内面に対して水平に照射されるレー ザーを，ミラーを使い照射方向を曲げ，レーザーを円筒 内面に当てるようにした，通常この状態でワーク側を回 転させれば円筒内面を加工することは可能である。しか し，エンジンシリンダなど，産業用に使用される部品に は大型のワークも多く, 大型のワークを回転させる為に は大きな力を必要とし, 必然的に装置自体も大型になっ てしまう。その為，ミラーを保持している軸を回転させ る事を可能な構成にし，大型ワークでもコンパクトな装 置で加工できる様なシステムとした。 またナノ周期構造 の形成はレーザーの偏光方向に依存することから， $\lambda / 2$ 板を使用した偏光制御軸を付加することで，照射面に任 意の偏光方向で照射できるようにしたため, 例えば水 平, 垂直, 交互など様々なパターンを加工することが可 能になっている。 上記回転2軸に, 直線XYZの3軸のス テージを使用することで複雑な形状を有する部品への加 工を可能にした。

また加工効率を上げるために，ビーム整形部には位相 板によってプロファイル形状を変更する機構を設けてい る。通常のガウシアン分布のプロファイルをトップハッ 卜型に整形することにより，有効にナノ周期構造を均一 に加工できる範囲を広げて，加工効率を上げる事が可能 となる。またこの機構はスロット交換式になっており, ガウシアン型，トップハット型，ガウシアン分布の多点 分岐が変更可能になっており，それぞれのニーズに対し て適したビーム形状を選んで加工する事が可能である. 


\section{6. 実用部品の加工事例}

本加工機は, 広いフルーエンス範囲を瞬時に制御でき るため, 数 $\mathrm{cm}$ の高低差があるような形状の摺動部品に 対して，その表面にナノ周期構造を安定に形成すること を可能にしている。たとえば段差のあるレール表面に加 工する場合でも，その段差毎に加工するのではなく，段 差を含んだ面を一度に全面加工することも可能になる。 本加工機は 4 軸 +1 軸の構成でレーザーの照射方向に自由 度をもたせることで様々な部品への加工を可能にしてい る.

燃費改善の取り組みで一番注目されている分野の一つ が自動車業界である。はじめにその業界の部品を加工し て検証することにした，摺動は大きく分けて滑りと転が りがあり, 滑りは主に平面, 転がりは球面での摺動にな る。どちらの摺動部品にも摩擦低減の需要は多く存在す る. 今回は滑り平面としてエンジンシリンダの内面, 転 がり平面としてベアリングに使用されるローラーの表面

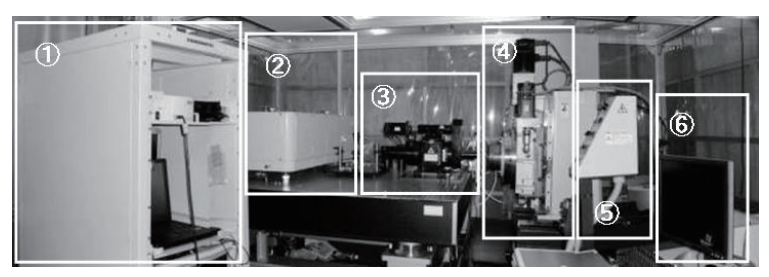

(I) General view of system.

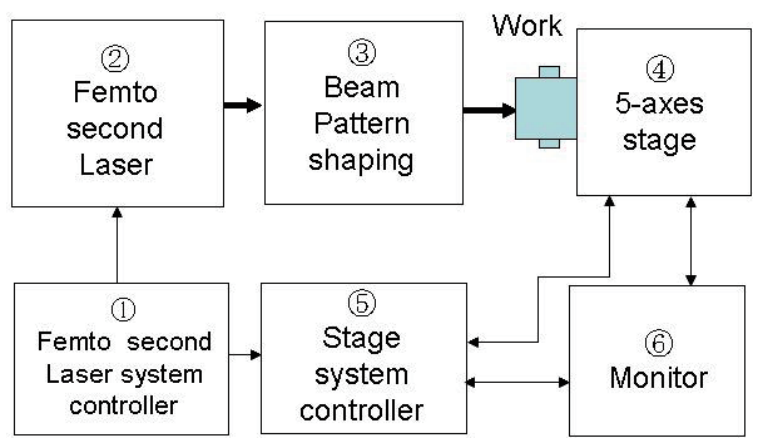

(II) Block diagram of the system.

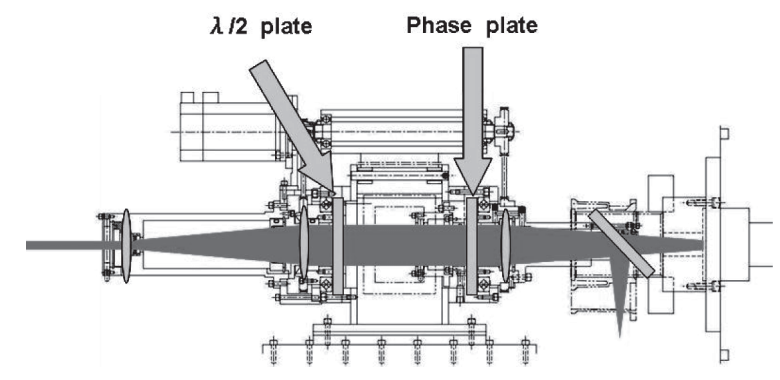

(III) Optical beam shaper.

Fig. 5 (I) Photograph of general view of system. (II) Schematic of femto-second laser machining system for nano periodic structures processing. (III) Optical beam shaper can change a profile to be efficient for the nano periodic structures processing by using a phase plate.
Table 1 Specifications of femto-second laser machine system with a 5-axes stage.

\begin{tabular}{|c|c|c|c|c|}
\hline \multicolumn{2}{|c|}{ Femto-second laser system } & \multicolumn{3}{|c|}{5 -axes stage } \\
\hline Wavelength & $780 \mathrm{~nm}$ & Axis & Stroke & Max speed \\
\hline Repetition rate & $2 \mathrm{kHz}$ & $\mathrm{X}$ & $500 \mathrm{~mm}$ & $10 \mathrm{~m} / \mathrm{min}$ \\
\hline Pulse width & $150 \mathrm{fs}$ & $\mathrm{Y}$ & $100 \mathrm{~mm}$ & $6 \mathrm{~m} / \mathrm{min}$ \\
\hline Average power & $2.0 \mathrm{~W}$ & $\mathrm{Z}$ & $300 \mathrm{~mm}$ & $10 \mathrm{~m} / \mathrm{min}$ \\
\hline \multirow[t]{2}{*}{ Beam diameter } & $4.51 \mathrm{~mm}$ & $\mathrm{C}$ & $360^{\circ}$ & 8.3 r.p.m. \\
\hline & & $\mathrm{L}$ & $360^{\circ}$ & 250 r.p.m. \\
\hline
\end{tabular}

への加工を行った. Fig. 6に加工結果を示す.

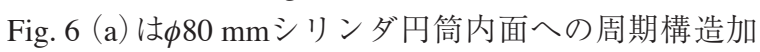
工である。様々なパターンで周期構造を加工する事がで きるようになっており，例えば全面均一，螺旋状，市松 模様など用途，効率に応じた加工が可能である.

Fig. 6 (b) は $\phi 60 \mathrm{~mm}$ のベアリングの円筒コロの表面に加 工を施したものである。本加工機を使用することで，円 筒内面，外面ともに自由に加工する事が出来る．また摺 動面によく使用される, 鋼球ボール表面のような3次元 形状表面にも周期構造を加工する事が可能である。

周期構造のパターン選択や, 複雑な表面への加工が可 能になった事で産業応用加工機としての応用範囲が拡大 されると考えている.今後はその用途に応じ, 適切な加 工を行える研究を行っていく予定である.

\section{7. おわりに}

フェムト秒レーザーによるナノ周期構造の加工は, ナ ノ秒レーザー加工装置などと比較すると容易であり，滑 り摺動での摩擦係数の低減効果も確認する事ができた. また, 摩擦低減効果の寿命についても初期摩耗により, ナノ周期構造は若干磨耗するものの, 潤滑効果により摩 擦係数の低減効果が維持される事も分かった。

今後の課題としては摺動の形態により, 摩擦係数の低 減効果がどの程度まで現れるのか調べていく予定であ る。摺動の形態は多様であり, 負荷過重, 滑り, 転が り, 直線運動, 往復運動, 潤滑油の種類, 潤滑油の供給 方法, 摺動速度, 摺動物質の種類, 形状, 状態等の因子 が複雑にからまっており, ここにナノ周期構造を使用し たとき，摺動方向に対する周期構造の方向や，深さ，間

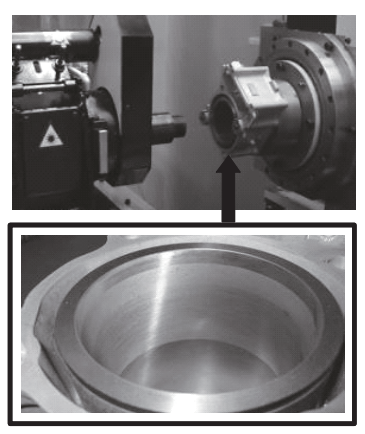

(a)

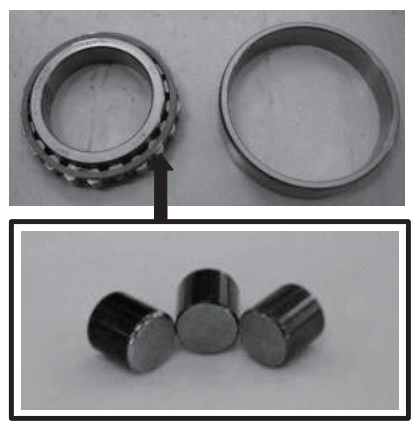

(b)
Fig. 6 Samples of 3D processing (a) inside of the $\phi 80 \mathrm{~mm}$ engine cylinder and (b) the surface of the $\phi 60 \mathrm{~mm}$ roller bearing. 
隔等が, どの様に影響するのかを調べる必要がある。

市販のフェムト秒レーザー装置は初期導入コストがま だ高価であることに加えて課題となるのは加工速度と考 えられる。自動車部品などの加工においては，ひとつの 行程を加工するのに数十秒ほどで行う必要がある。現状 のフェムト秒レーザーの能力では使用環境の制限や, 平 均出力が低い為加工効率が低く, 一般の加工生産ライン に組み込む事は難しい。しかしながらフェムト秒レー ザーの開発も日進月歩であり, 能力向上も著しいものが ある. $\mathrm{CO}_{2}$ やYAGレーザー, 半導体レーザーの様に，一 般の生産ラインに組み込まれるのも遠い未来の話ではな いだろう。

\section{参考文献}

1) P. E. Dyer and R. J. Farley: Appl. Phys. Lett. 57 (1999) 765.

2) H. Hiraoka and M. Sendova: Appl. Phys. Lett. 64 (1994) 563.

3) M. Bolle and S. Lazare: Appl. Phys. Lett. 60 (1992) 674.

4) W. Demtroeder: Laser Spectroscopy, Basic Concepts and Instrumentation (Springer 1996) 114.

5) 澤田 博司：精密工学会誌 69 (2003) 554.

6）藤田 雅之：ILT2005年報（2005） 23 .

7) 山本智志, 篠永東吾, 中野人志, 塚本 雅裕, 柴柳俊哉, 阿部信行, 本田博史, 藤田雅之, 王新敏, 和田武, 吉村 昌弘：レーザ加工学会講演論文集 71 (2008) 181.

8）川原公介, 沢田博司, 武田昭二, 甲藤 正人：電気学会研 究会資料 OQD-06-1（2006）1.

9) M. Weikert, C. Fohl, F. Dausinger, and T. Abeln: Proc. SPIE 5063 (2003) 208.

10）加藤 貴行, 阿部 信行, 山中 正宣, 松本 康太郎：レーザー 研究 36 (2008) 144.

11) 村木 正芳：トライボロジー 摩擦の科学と潤滑技術（日刊 工業新聞社, 2007) 4 .

12) 村木 正芳：トライボロジー 摩擦の科学と潤滑技術（日刊 工業新聞社, 2007) 46 . 